九州大学学術情報リポジトリ

Kyushu University Institutional Repository

\title{
Distribution and Composition of Flavonols in the Flowers of Rhododendron oldhami i Maxim.
}

Huyen, Dao Thi Thanh

Graduate School of Bioresource and Bioenvironmental Science, Kyushu University

Van, Dao Thanh

Thai Nguyen University of Agriculture and Forestry

Huang, KuangLiang

Department of Horticultural Science, National Chiayi University

Miyaj ima, Ikuo

Institute of Tropical Agriculture, Kyushu University

https://doi.org/10.5109/1564078

出版情報：九州大学大学院農学研究院紀要. 61 (1)，pp.37-40，2016-02-29. Faculty of Agriculture， Kyushu University

バージョン :

権利関係 : 


\title{
Distribution and Composition of Flavonols in the Flowers of Rhododendron oldhamii Maxim.
}

\author{
Dao Thi Thanh HUYEN ${ }^{1}$, Dao Thanh VAN ${ }^{2}$, KuangLiang HUANG ${ }^{3}$ \\ and Ikuo MIYAJIMA*
}

Institute of Tropical Agriculture, Kyushu University, Fukuoka 812-8581 Japan

(Received November 9, 2015 and accepted November 19, 2015)

\begin{abstract}
Rhododendron oldhamii Maxim. is an endemic evergreen azalea in Taiwan and recently planted in Japan. This species is distributed from $150 \mathrm{~m}$ to $2,700 \mathrm{~m}$ above sea level. Red-flowered species with petal color ranging from orange to red normally contain only cyanidin series anthocyanins and no flavonols in their petals. However, the color of blotches on the upper lobe of the petals or at the base of the funnel is slightly reddish-purple that suggested the presence of flavonols. In $R$. oldhamii, cyanidin 3-arabinoside and cyanidin 3-galactoside are two major anthocyanins in both upper and lower petals but flavonols were only detected in the upper petals, specifically in the blotches areas, by HPLC analysis. Two major flavonols were identified as quercetin glycosides. The $\mathrm{pH}$ value of reddish-purple blotches was slightly higher than that of surrounding areas and lower petals. These results indicated that co-pigmentation between cyanidin glycosides and quercetin glycosides pigments associated with higher $\mathrm{pH}$ condition, causing reddish-purple color for blotches in $R$. oldhamii flowers.
\end{abstract}

Key words: anthocyanin, copigmentation, flavonol, Rhododendron oldhamii

\section{INTRODUCTION}

Rhododendron oldhamii Maxim., classified in the subgenus Tsutsusi, is a subtropical broadleaf species endemic to Taiwan and was scientifically described for the first time in 1870 (Hsieh et al., 2013). This species is distributed from $150 \mathrm{~m}$ to $2,700 \mathrm{~m}$ above sea level, and the population size of it is the largest among all Rhododendrons in Taiwan. It is commonly used as important ornamental plants for gardens, street plantings or flowerpots because of the beauty of flowers and multiple flowering seasons per year.

Rhododendron oldhamii is semideciduous shrubs with red, brick-red or orange five-petal-lobe flowers and reddish-purple blotches on the upper insides of the petals (Fig. 1). Pigment components of some red flowered species such as $R$. simsii, $R$. indicum and $R$. oldhamii flowers have been reported to be cyanidin 3-galactoside and cyanidin 3-arabinoside as two major anthocyanins in whole flower petals (Hang et al., 2011). However, the development of the reddish-purple color of blotches in $R$. oldhamii has not been well analyzed and explained. In azaleas, it is well-known that co-pigmentation between anthocyanins and flavonols has a bluing effect for flower color (Asen et al., 1971; De Loose, 1978). Reddish-purple blotches of $R$. oldhamii suggest the existence of kind of co-pigments, which should be revealed.

The purpose of this study is to clarify the distribution and composition of pigments in reddish-purple

${ }^{1}$ Graduate School of Bioresource and Bioenvironmental Science, Kyushu University, Fukuoka 8128581 Japan

2 Thai Nguyen University of Agriculture and Forestry, Thai Nguyen 252161, Vietnam

${ }^{3}$ Department of Horticultural Science, National Chiayi University, Chiayi 60004, Taiwan, ROC.

* Corresponding author: (E-mail: imiyajima@agr.kyushuu.ac.jp).

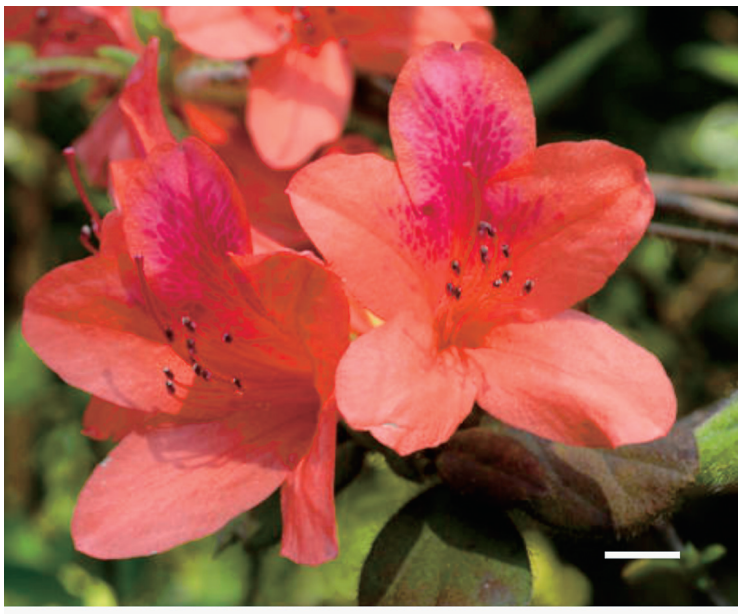

Fig. 1. Full opened Rhododendron oldhamii flowers. Bar indicates $1 \mathrm{~cm}$.

blotches of $R$. oldhamii petals by anatomical and chromatographic methods.

\section{MATERIALS AND METHODS}

\section{Plant materials}

Full-opened $R$. oldhamii flowers were collected at Kyushu University greenhouse. A part of fresh petals was used for microscopic observation of the cross-sections. The remaining was separated into upper and lower petals, and each part of petals was boiled at $100^{\circ} \mathrm{C}$ for $5 \mathrm{sec}$ onds and immediately cooled in water. Then the samples were dried in the forced convention oven overnight at $50^{\circ} \mathrm{C}$. The dried samples were stored in a desiccator at $4^{\circ} \mathrm{C}$ until using for pigment analysis. 


\section{Microscopic observation of pigment distribution and absorption spectra of fresh petals}

Upper and lower petals of fresh flowers of $R$. oldhamii were cut into small squares at the center positions and fixed using $5 \%$ agar in the petri dish. Then they were sliced using a microslicer (DTK-1000, Dosaka EM; Kyoto, Japan) at a thickness of $150 \mu \mathrm{m}$. After slicing, cross-sections were observed under an optical microscope (Leica DM-2500; Leica Microsystems GmbH, Wetzlar, Germany).

\section{HPLC analysis}

Dried petals (ca. $50 \mathrm{mg}$ ) of $R$. oldhamii were soaked overnight with $50 \% \mathrm{HOAc}-\mathrm{H}_{2} \mathrm{O}$. After filtration, analytical HPLC was conducted on a LC-20AD pump (Shimadzu, Kyoto, Japan), using a Cosmosil 5 $\mathrm{C}_{18}$ MS-II column (4.6 $\phi \times 250 \mathrm{~mm}$; Nakalai Tesque, Kyoto, Japan) at $40^{\circ} \mathrm{C}$ with a flow rate of $1 \mathrm{~mL} \cdot \mathrm{min}^{-1}$, and monitoring at $520 \mathrm{~nm}$ and $360 \mathrm{~nm}$ for anthocyanins and flavonols, respectively. A linear gradient elution was applied for $40 \mathrm{~min}$ from 20 to $85 \%$ solvent $\mathrm{B}\left(1.5 \% \mathrm{H}_{3} \mathrm{PO}_{4}, 20 \% \mathrm{HOAc}, 25 \% \mathrm{MeCN}\right.$ in $\left.\mathrm{H}_{2} \mathrm{O}\right)$ in solvent $\mathrm{A}\left(1.5 \% \mathrm{H}_{3} \mathrm{PO}_{4}\right.$ in $\left.\mathrm{H}_{2} \mathrm{O}\right)$.

\section{Identification of pigments}

Two-dimensional thin layer chromatography (TLC) was carried out on cellulose-coated glass plates (Merck, Darmstadt, Germany) using two mobile phases: BAW $\left(1-\mathrm{BuOH} / \mathrm{HOAc} / \mathrm{H}_{2} \mathrm{O}, 4: 1: 2, \mathrm{v} / \mathrm{v} / \mathrm{v}\right)$ and $10 \% \mathrm{HOAc}$. The plates were observed under the UV light ( $365 \mathrm{~nm})$, and the color of all spots was recorded. Subsequently, each spot was collected from the TLC plates, and dissolved using $\mathrm{MeOH}$ for HPLC analysis.

\section{Isolation of major flavonols}

Dried petals (ca. $0.7 \mathrm{~g}$ ) of $R$. oldhamii were soaked overnight with $100 \% \mathrm{MeOH}$. After filtration, preparative HPLC was performed on an LC-6AD system (Shimadzu, Kyoto, Japan), using a Cosmosil $5 \mathrm{C}_{18}$ AR column (20 $\phi \times$ $250 \mathrm{~mm}$; Nakalai Tesque, Kyoto, Japan) at $40^{\circ} \mathrm{C}$ with a flow rate of $9 \mathrm{~mL} \cdot \mathrm{min}^{-1}$, and monitoring at $360 \mathrm{~nm}$ for isolation of major flavonol peaks. A linear gradient elution was applied for 40 min from 50 to $85 \%$ solvent B (10\% formic acid, $40 \% \mathrm{MeCN}$ in $\mathrm{H}_{2} \mathrm{O}$ ) in solvent A (10\% formic acid in $\mathrm{H}_{2} \mathrm{O}$ ). Major peaks were obtained using a fraction collector.

\section{Identification of flavonol aglycones}

Each purified flavonol was acid hydrolyzed by $2 \mathrm{~N}$ $\mathrm{HCl}$ at $100^{\circ} \mathrm{C}$ for $90 \mathrm{~min}$. The flavonol aglycones were cochromatographed with authentic standard flavonols aglycones such as myricetin, quercetin and kaempferol, by HPLC with constant flow of $75 \%$ solvent A (0.1 M HOAc): $25 \%$ solvent B (MeCN). The HPLC system, column, and flow rate were the same as mentioned above (HPLC analysis). Wavelength was set at $360 \mathrm{~nm}$.

\section{pH measurement}

Fresh flowers of $R$. oldhamii were separated into blotches, surrounding areas of botches and lower petals. The $\mathrm{pH}$ value of squeezed juice of each part was deter- mined using a compact $\mathrm{pH}$ meter (TWIN $\mathrm{pH}$ waterproof B-212; Horiba Ltd., Kyoto, Japan). Five flowers were measured as replications.

\section{RESULTS AND DISCUSSION}

\section{Distribution of pigmented cells in the petals of $\boldsymbol{R}$. oldhamii flowers}

Blotches of $R$. oldhamii flowers showed numerous reddish-purple pigmented cells, which accumulated in the adaxial epidermis of upper petals (Fig. 2B). On the other hand, red colored cells were distributed in the epidermis of both upper and lower petals (Fig. 2B, C). The upper epidermis of blotch areas was flat, and the shape of reddish-purple pigmented cells was not different from that of red pigmented cells. Generally, blotches in flowers of Rhododendron species contain stronger colored cells in the adaxial subepidermis rather than in epidermis. (Pecherer, 1992). The same results were observed in the transverse section of red blotches in R. schlippenbachii flowers. While light pink colored cells accumulated in the upper epidermis, red pigments were distributed in subepidermal cells (Yamagishi and Akagi, 2013). In $R$. oldhamii flowers, reddish-purple pigmented cells are only distributed in adaxial subepidermis of blotches areas.

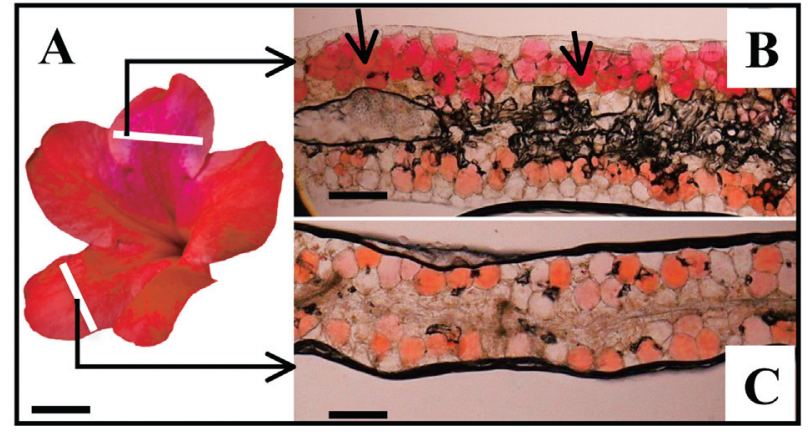

Fig. 2. Cross-sections of flower petals of $R$. oldhamii. A: Whole flower, B: Cross-section of upper petal, C: Cross-section of lower petal.

White lines in the photo A indicate sliced positions. Arrows in the photo B indicate reddish-purple cells. Bars: photo $\mathrm{A}=$ $1 \mathrm{~cm}$, photo $\mathrm{B}$ and $\mathrm{C}=20 \mu \mathrm{m}$

\section{Pigment composition in flower petals}

Both upper and lower petals contained two major anthocyanins (Fig. 3A). These two anthocyanin pigments were reexamined and confirmed to be cyanidin 3-galactoside (Cy 3Ga) and cyanidin 3-arabinoside (Cy 3Ar) as previously reported in red flowered $R$. simsii and $R$. oldhamii as well (Hang et al., 2011). At the absorbance of $360 \mathrm{~nm}$, two major peaks were detected in upper petals, while no major peak was detected in lower petals (Fig. 3B). Thus, these two flavonoids seem to be present only in upper petals of $R$. oldhamii flowers.

To identify these two major flavonoids in upper petals, two-dimensional TLC was carried out. Eight discrete spots appeared in the TLC plates (Fig. 4) and color properties were recorded under visible and UV light 
Table 1. Rf values and color properties of spots of pigments extracted from $R$. oldhamii flowers and separated by two-dimensional thin layer chromatography

\begin{tabular}{ccccc}
\hline \multirow{2}{*}{ Spot No. } & \multicolumn{2}{c}{ Rf value $(\times 100)$} & \multicolumn{2}{c}{ Color in } \\
\cline { 2 - 5 } & BAW $^{1)}$ & $10 \%$ AcOH & Visible light & UV-light \\
\hline 1 & 17 & 22 & Red-lilac & Violet \\
2 & 48 & 14 & Red-lilac & Violet \\
3 & 65 & 20 & Pale brown & Yellow F. ${ }^{3)}$ \\
4 & 76 & 30 & Pale brown & Yellow F. \\
5 & 75 & 48 & $-{ }^{2)}$ & Blue F. \\
6 & 39 & 50 & - & Blue F. \\
7 & 64 & 66 & - & Blue F. \\
8 & 37 & 70 & - & Blue F. \\
\hline
\end{tabular}

\footnotetext{
1) $1-\mathrm{BuOH} / \mathrm{HOAc} / \mathrm{H}_{2} \mathrm{O}=4: 1: 2, \mathrm{v} / \mathrm{v} / \mathrm{v}$

2) colorless.

${ }^{3)}$ fluorescent.
}

A

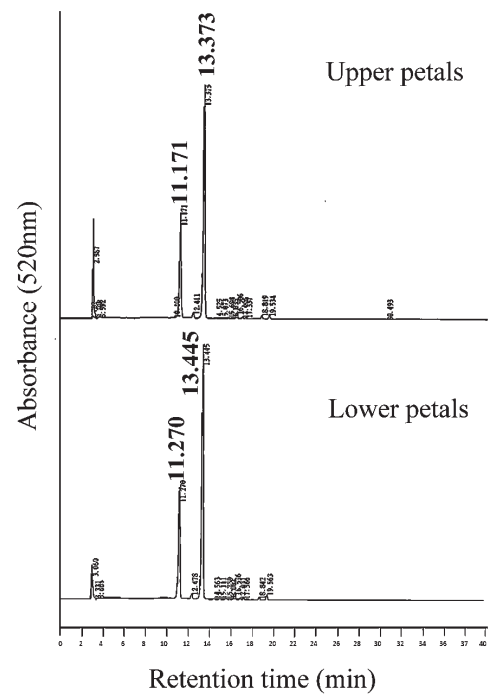

B

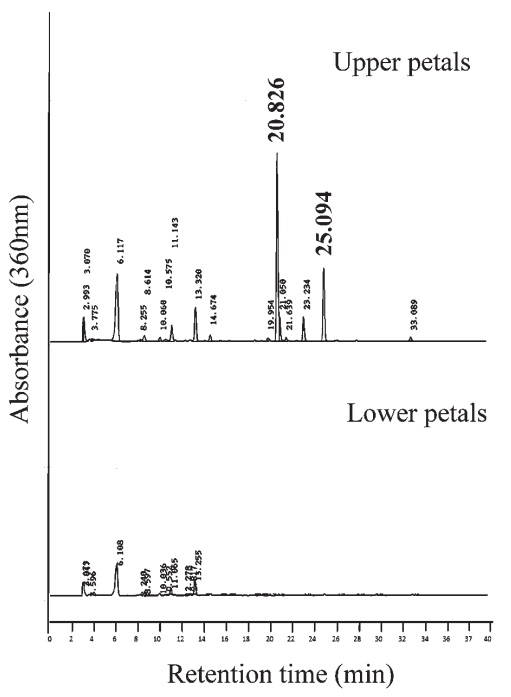

Fig. 3. HPLC profiles of the extracts from upper and lower petals of $R$. oldhamii at $520 \mathrm{~nm}(\mathrm{~A})$ and $360 \mathrm{~nm}(\mathrm{~B})$.

(Table 1). Spot numbers 1 and 2 expressed red-lilac color under visible light and violet under UV light. This result suggested that they were two major anthocyanins (Cy $3 \mathrm{Ga}$ and $\mathrm{Cy} 3 \mathrm{Ar}$ ). In addition, spots 3 and 4 appeared pale brown under visible light, and showed yellow florescence under UV light. Spethmann (1980) investigated flavonoids of Rhododendron flowers, and reported that some flavonol glycosides, such as quercetin 3-arabinoside, quercetin 3-rhamnoside or kaempferol 5-methylether, appeared brown or pale brown under visible light and colored greenish-yellow to yellow florescence under UV light on TLC plate. These findings suggested that spots 3 and 4 are flavonols. The HPLC analysis of spots 3 and 4 was carried out after collection and extraction from TLC plate. From HPLC analysis, spots 3 and 4 coincided with two major peaks in upper petals (Fig. 3B).

Next, these two major peaks in upper petals were isolated by preparative HPLC and acid hydrolyzed using $2 \mathrm{~N} \mathrm{HCl}$. HPLC analysis showed that two major peaks

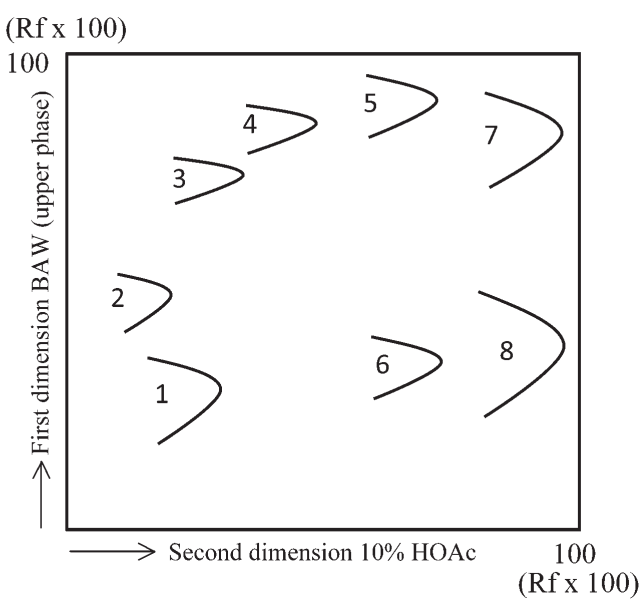

Fig. 4. Two-dimensional thin layer chromatogram of $\mathrm{MeOH}$ extract from upper petals of $R$. oldhamii flowers. BAW (1-BuOH/HOAc/ $\mathrm{H}_{2} \mathrm{O}, 4: 1: 2$, v/v/v). See Table 1 for color properties of spots. 
Table 2. HPLC retention time of standard flavonols and flavonol aglycones of $R$. oldhamii flowers

\begin{tabular}{cc}
\hline Aglycones & Retention times (min) \\
\hline Myricetin & 8.0 \\
Quercetin & 15.2 \\
Kaempferol & 28.8 \\
\hline Peak 1 & 15.2 \\
Peak 2 & 15.2 \\
\hline
\end{tabular}

Table 3. $\mathrm{pH}$ value of the flower parts of $R$. oldhamii

\begin{tabular}{cc}
\hline Flower parts & $\mathrm{pH}$ value \\
\hline Blotches & $3.14 \mathrm{a}^{1)}$ \\
Surrounding areas of blotches & $2.18 \mathrm{~b}$ \\
Lower petal & $2.26 \mathrm{~b}$ \\
\hline
\end{tabular}

${ }^{1)}$ Values with different letters are significantly different at $P<0.05$ by Tukey's test.

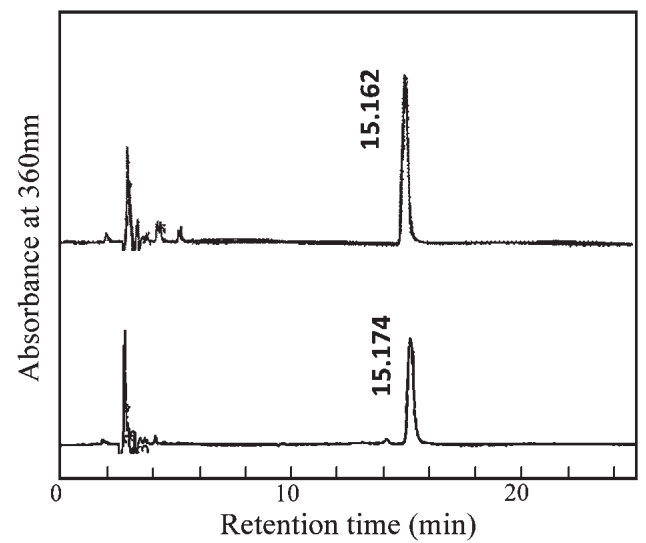

Fig. 5. HPLC tracing of acid hydrolysates of two major flavonols isolated from the petals of $R$. oldhamii.

have same flavonol aglycones at the retention time of 15 min (Fig. 4). In comparison to authentic standard samples, such as myricetin, quercetin and kaempferol, the aglycones of two major peaks were identified as quercetin (Table 2).

Asen et al. (1971) determined the cause of the difference in color expression between 'Red Wing' azalea and an orange sport of this cultivar. The orange color of the mutant was due to cyanidin glycosides, whereas the color of 'Red Wing' azalea was due to the same cyanidin glycosides co-pigmented with quercetin glycosides. Carmine red color of some cultivar of azalea species, such as 'Vuyk's Scarlet', is in effect produced by the addition of flavonol (quercetin-glycosides) to the red pigments cyanidin or peonidin (Heursel, 1987). Thus, quer- cetin glycosides co-pigmented with cyanidin glycosides to develop 'bluing effect' causing reddish-purple blotches in $R$. oldhamii flowers.

\section{pH value of petal parts}

The $\mathrm{pH}$ value of the pressed juice from various positions of same flowers was quite different. The $\mathrm{pH}$ of reddish-purple blotches was 3.14. On the other hand, that value of surrounding areas of blotches and lower petals were 2.18 and 2.26 , respectively. The same results were also reported by Stewart et al. (1975) in fuchsia cv. Fanfare flowers. The $\mathrm{pH}$ of pink calyx was 4.1 , while that of the strong red corolla was 3.7. The $\mathrm{pH}$ of reddishpurple blotch areas was higher than that of red petal parts. However, petal color is not only determined by $\mathrm{pH}$ value, but also by co-pigments or other inorganic substances, such as $\mathrm{Al}^{3+}$ (Yoshida et al., 2003).

In conclusion, these results indicated that co-pigmentation between cyanidin glycosides and quercetin glycosides pigments associated with higher $\mathrm{pH}$ condition, causing reddish-purple color for blotches in R. oldhamii flowers.

\section{REFERENCES}

Asen, S., R. N. Stewart and K. H. Norris 1971 Co-pigmentation effect of quercetin glycosides on absorption characteristics of cyanidin glycosides and color of Red Wing azalea. Phytochem. 10: $171-175$

De Loose, R. 1978 Azalea indica flower color as related to the parameters $\mathrm{pH}$, anthocyanins and flavonol co-pigments. Scientia Hortic. 9: 285-290

Hang, T. T. N., I. Miyajima, K. Ureshino, N. Kobayashi, Y. Kurashige, T. Matsui and H. Okubo 2011 Anthocyanins of wild Rhododendron simsii. Planch. flowers in Vietnam and Japan. J. Japan. Soc. Hort. Sci. 80: 206-213

Hsieh, Y. C., J. D. Chung, C. N. Wang, C. T Chang, C.Y Chen and S. Y. Hwang 2013 Historical connectivity, contemporary isolation and local adaptation in a widespread but discontinuously distributed species endemic to Taiwan, Rhododendron oldhamii (Ericaceae). Heredity 111: 147-156

Heursel, J. 1987 Inheritance of flower colors and breeding of evergreen azaleas. J. Amer. Rhododendron Soc. 41(3) <http:// scholar.lib.vt.edu/ejournals/JARS/v41n3/v41n3-heursel.htm>.

Pecherer, B. 1992 The color of Rhododendron flowers. J. Amer. Rhododendron Soc. 46(4) <http://scholar.lib.vt.edu/ejournals/ JARS/v46n4/v46n4-pecherer.htm>.

Spethmann, W. 1980 Flavonoids and carotenoids of Rhododendron flowers and their significance for the classification of the genus Rhododendron. pp. 247-276. In: J. L. Luteyn and M. E. O'Brien (eds.). Contributions toward a classification of Rhododendron. New York Bot. Garden, New York

Stewart, R. N., K. H. Norris and S. Asen 1975 Microspectrophotometric measurement of $\mathrm{pH}$ and $\mathrm{pH}$ effect on color of petal epidermal cells. Phytochem. 14: 937-942

Yamagishi, M and K. Akagi 2013 Morphological and heredity of tepal spots in Asiatic and Oriental hybrid lilies (Lilium spp.). Euphytica 194: 325-334

Yoshida, K., Y. Toyama-Kato, K. Kameda and T. Kondo 2003 S epal color variation of Hydrangea macrophylla and vacuolar $\mathrm{pH}$ measured with a proton-selective microelectrode. Plant Cell Physiol. 44(3): 262-268 